\title{
Root Nodule Preparation as a Low-Cost Inoculant for Cowpea
}

\author{
Marcelo de S. Pinheiro ${ }^{1}$, Leane F. de Melo ${ }^{1}$, Claudia M. Martins ${ }^{1}$, Suzana C. S. Martins ${ }^{1}$, \\ Norma G. Rumjanek ${ }^{2}$, \& Cândida H. C. de M. Bertini ${ }^{1}$ \\ ${ }^{1}$ Federal University of Ceará, Fortaleza, CE, Brazil \\ ${ }^{2}$ Embrapa Agrobiologia, Seropédica, RJ, Brazil \\ Correspondence: Marcelo de Sousa Pinheiro, Federal University of Ceará, Fortaleza, Brazil. E-mail: \\ marcelospufc@gmail.com
}

Received: April 23, 2019

Accepted: June 10, 2019

Online Published: August 31, 2019

doi:10.5539/jas.v11n14p265

URL: https://doi.org/10.5539/jas.v11n14p265

The research is financed by CAPES.

\begin{abstract}
Widely grown in diverse regions of Brazil, cowpea has high nutritional value, is easily cultivated, and can fix nitrogen $(\mathrm{N})$ symbiotically. Although there are commercial inoculants for cowpea, it is difficult for small producers to acquire them. A nodule preparation is an inexpensive and easily prepared option for small farmers. The aim of this study was to test a nodule preparation as a low-cost inoculant, increasing cowpea seed grain production. Thus, different cowpea cultivars were compared in two locations, the municipalities of Crato and Madalena, both in Ceará. Two field experiments were performed to evaluate gain derived from this inoculation method. The nodule preparation was created from nodules removed from roots of cowpea grown in the experimental locations. The nodules were macerated and added to water, obtaining a liquid (inoculant) that was applied to the seeds. The experiment was conducted following a randomized block design with four replicates and a $4 \times 3$ factorial arrangement ( $\mathrm{N}$ sources $\times$ cultivars). Results indicate little interaction between the sources of $\mathrm{N}$ and the cultivars because only the shoot dry matter (Crato experiment) exhibited interaction between both. The differences provided by the nodule preparation were more notable among cultivars and between the environments, Crato and Madalena. The nodule preparation differed little from the commercial inoculant; they were comparable. However, gain in relation to the zero control also proved to be reduced, indicating little contribution of the nodule preparation to cowpea under the conditions tested.
\end{abstract}

Keywords: legumes, plant nutrition, rhizobia, yield

\section{Introduction}

Cowpea is one of the most important grain-producing legumes in tropical and subtropical regions in the world and is one of the main sources of proteins, calories, crude fiber, minerals, and vitamins for a large number of people throughout the world (Phillips et al., 2003). In Brazil, this crop is highly relevant, especially in the North and Northeast regions, which concentrate $84 \%$ of the areas planted to cowpea. However, the Central-West region, and most notably the state of Mato Grosso, has a planted area of 209 thousand hectares and a yield that exceeds $1000 \mathrm{~kg} \mathrm{ha}^{-1}$ (CONAB, 2018). The crop is also well known for its tolerance to unfavorable edaphic and climatic conditions, as well as promotion of recognized nutritional benefits for local populations.

Legume species such as cowpea are used in crop rotation, providing protection to the soil, reducing erosion, and even serving as a green manure crop to improve soil fertility (Kambashi et al., 2014; Timko et al., 2007). Although cowpea shows high adaptability to unfavorable climate and soil conditions, there are impediments to a higher mean yield, brought about by problems such as irregular rains or inadequate irrigation, plant health problems, or a production system that incorporates little technology in sowing and management of the crop. Some producers seek to adopt mechanization at all stages of the crop to improve the production system, optimizing the steps in production, from sowing to harvest (Matos Filho et al., 2009).

The use of mineral fertilization to supply nitrogen $(\mathrm{N})$ is a high cost process that is not very accessible to small producers; in addition, it is potentially more polluting, due to the risk of groundwater contamination from nitrate (Moreira \& Siqueira, 2006). 
In this respect, growing cowpea has the distinct advantage of being able to establish symbiosis with root nodulating bacteria (rhizobia). Rhizobia, for their part, can establish symbiotic association with legume species, increasing crop production and soil organic matter content. In this environment, the adoption of rhizobia strains efficient in biological $\mathrm{N}$ fixation (BNF) can supply cowpea with the adequate amount of $\mathrm{N}$ required for its development, increasing production without increasing costs (Rufini et al., 2014).

Rhizobia are excellent examples of soil bacteria capable of providing nutrients for plant growth. When they are in the initial stages of symbiosis, the molecular complex promotes communication involving Nod factors, synthetized by the bacteria and flavonoids released by the roots of the legume; both become symbiotic partners and can recognize one another and begin nodulation (Oldroyd, 2013).

In the soybean crop, adoption of inoculants to replace nitrogen fertilizers has made the crop very competitive internationally. The savings generated is around U\$ 9.8 billion/year (Reis Júnior et al., 2011). For cowpea, there are already strains recommended; however, they may have wide variability in response according to the specificity of the crop (Soares, 2007). Another difficulty in the association of rhizobia with cowpea is the promiscuity of cowpea, which can establish symbiosis with a variety of nodulating bacteria. However, there is a more limited response of the crop when it is inoculated with strains selected in the field (Guimarães et al., 2012; Moreira, 2006).

BNF in legumes has proven to be quite variable depending on the species, and its adoption has significant potential for improving cowpea nutrition (Alcântara et al., 2014). Native rhizobia in the soil are highly important for legumes by providing for greater growth of these species; however, their performance depends on the size of the population, survival capacity, and effectiveness of plants in fixation of these native populations (Sanginga et al., 1996; Sinnsiri \& Homchan, 2002).

Although the practice of inoculation is widely used in the soybean crop and even in second crop common bean on large agricultural properties, the practice is not often used on small properties directed toward family farm agriculture. Many small farmers are unaware of this product, and those that have knowledge of it are unable to acquire it, due to the distance from production and distribution centers. Since it is a biological product, its durability is reduced (durability of approximately six months). This becomes an obstacle to crop and livestock product shops if the stocks of the product are not all sold within the period of the crop season.

Within this context, the aim of this study was to test the use of a nodule preparation as an alternative low-cost inoculant that is easy to prepare and that can increase production of cowpea grain for small farmers.

\section{Method}

\subsection{Nodule Preparation}

The alternative inoculant was made from a preparation of root nodules from cowpea cv. Setentão in a small area near the location where the experiment was set up. This area consisted of six $5-\mathrm{m}$ rows with dimensions of $5 \times$ $20 \mathrm{~m}$. After 35 days, the plants were removed, and the roots carefully washed for minimum loss of nodules. After that, the nodules were detached from the roots and placed in a glass container to which water was added, equivalent to double the volume of the nodules, and the material was macerated. Seeds for use in plots with the treatment of inoculation with the nodule preparation were immersed in the container with the macerated nodules, remaining at rest for 10 minutes. They were then placed to dry on a flat surface over paper toweling. After this phase, the seeds were placed in bags for transport to the field. The entire procedure was carried out on the afternoon prior to sowing day because inoculation should be carried out a maximum of $24 \mathrm{~h}$ before sowing in the field, at risk of the seeds becoming inadequate for sowing.

\subsection{Field Experiment}

To confirm the agronomic efficiency of the nodule preparations under field conditions two experiments were carried out, the first in Crato, CE, in the south of the state $\left(07^{\circ} 14^{\prime} 08.8^{\prime \prime} \mathrm{S} 39^{\circ} 22^{\prime} 09.8^{\prime \prime} \mathrm{W}\right)$ in the period of February to May 2017, and the second, from March to June 2017, in Madalena, CE, in the central hinterlands

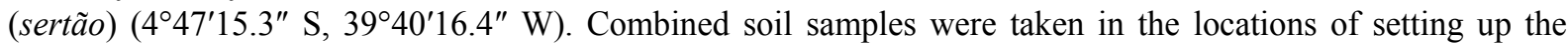
experiments at the depth of $0-20 \mathrm{~cm}$ for soil fertility analyses (Table 1).

The experiments were set up following a randomized block design in a $3 \times 4$ factorial arrangement, with four replicates. The first factor was composed of the following cowpea cultivars: Sempre Verde, Setentão, and BRS Guariba. The second factor was composed of four sources of N: nodule preparation (NP), commercial inoculant (INOC), nitrogen fertilized control (NFC) that received only chemical fertilization at the rate of $50 \mathrm{~kg} \mathrm{ha}^{-1}$ of N in the form of urea, and the absolute control ( $\mathrm{C} 0$ ), free of addition of $\mathrm{N}$ and inoculant. 
Table 1. Fertility analysis of the soils where the field analyses were carried out

\begin{tabular}{llllllll}
\hline Local & $\mathrm{pH}$ & $\mathrm{Ca}^{2+}$ & $\mathrm{Mg}^{2+}$ & $\mathrm{K}^{+}$ & $\mathrm{P}$ & O.M. & Texture \\
\hline & water & -------- & $\mathrm{cmolc} \mathrm{kg}^{-1}----$ & & $\mathrm{mg} \mathrm{kg}^{-1}$ & $\mathrm{~g} \mathrm{~kg}^{-1}$ & \\
Crato & 5.2 & 0.5 & 0.4 & 0.13 & 2 & 4.76 & sandy \\
Madalena & 5.4 & 2.4 & 1.9 & 0.31 & 5 & 9.41 & medium \\
\hline
\end{tabular}

Note. O.M. = Organic Matter.

The area was first tilled through plowing and disking. Each block was constituted of 12 plots, each plot measuring $5 \mathrm{~m}$ length and $3.2 \mathrm{~m}$ width, containing six rows at a spacing of $0.8 \mathrm{~m}$, with $0.30 \mathrm{~m}$ between plants. Each block had an approximate length of $58 \mathrm{~m}$ and spacing between blocks was $1.5 \mathrm{~m}$.

Three seeds were sown per plant hole, but only one plant was left after thinning, performed 14 days after sowing. The plots were fertilized with only $\mathrm{K}_{2} \mathrm{O}$ in the form of $\mathrm{KCl}$ and $\mathrm{P}_{2} \mathrm{O}_{5}$ in the form of single superphosphate; only the positive control received application of urea. The plants were monitored weekly and, when necessary, plant health control measures and weeding were performed for control of pests and weeds, respectively.

At 35 days after planting, two plants were collected per plot for analysis of root and shoot dry matter. The plants were carefully removed by digging around them to have minimum loss of roots. Then, the shoots and the roots were separated, and placed separately in paper bags. The roots were washed and then dried in a laboratory oven at $65^{\circ} \mathrm{C}$ for 72 hours.

The following variables were analyzed: Shoot Dry Matter (SDM), Root Dry Matter (RDM), Pod Length (PL), Number of Pods per Plant (NPP), Number of Seeds per Pod (NSP), Pod Weight (PW), Weight of Seeds per Pod (WSP), Yield (YIELD), and 100 Seed Weight (100SW).

Analysis of Variance was conducted on the results and, subsequently, the means were compared by the Tukey test at the level of 5\% significance, with analyses performed by the Genes software (Cruz, 2013).

\section{Results and Discussion}

The nitrogen sources evaluated in the first locale (Crato) were not influenced by the choice of the cowpea cultivars, indicating no interaction between the two factors, except for the variable SDM $(\mathrm{P}<0.05)$. Although the $\mathrm{N}$ sources were not significantly different regarding the variables analyzed, the cowpea cultivars were significantly different from each other $(\mathrm{P}<0.01)$ with respect to nearly all the variables, the exceptions being PW, RDM, WSP and YELD (Table 2).

In the second locale (Madalena), there were no significant differences between the treatments, but between the environments there were variables that differed significantly (PL, NSP and 100SW). No variable presented a significant interaction of $\mathrm{N}$ source $\times$ cultivar, indicating absence of interaction between these factors. The values of CV in Crato varied from 4.85 (PL) to $51.51(\mathrm{PW})$, while in Madalena the values ranged from 4.02 (PL) to 49.01 (NPP). According to Pimentel-Gomes and Garcia (2002), the coeficiente of variation helps to determine the variability of the data analyzed.

Results showed that the treatments differed little in relation to most of the variables because they did not exhibit statistically significant differences. The plots inoculated with the nodule preparation were identical to the controls, both for the experiment conducted in Crato and for the experiment conducted in Madalena. The only variable that exhibited interaction between the cultivars and the N sources was SDM in Crato (Figure 1), in which the cultivar Setentão with the mineral nitrogen treatment had the best value $\left(27.48 \mathrm{~g} \mathrm{pl}^{-1}\right)$. The second best value was observed with the nodule preparation treatment, with $24.52 \mathrm{~g} \mathrm{pl}^{-1}$. In the second location (Madalena-CE), the results for these variables had the same behavior, though with lower mean values (Figure 1).

The SDM of the experiment conducted in Crato exhibited differences among the cultivars compared within the mineral $\mathrm{N}$ fertilized treatment and also in the treatment inoculated with the nodule preparation. The cultivar Setentão was superior to the cultivar Sempre Verde (Figure 1). When we compared the sources of N, there were no differences within the cultivar Setentão and BRS Guariba, only for the cultivar Sempre Verde. 
Table 2. Summary of the analysis of variance for the effect of nitrogen source with different cowpea cultivars in two locales

\begin{tabular}{|c|c|c|c|c|c|c|c|c|c|c|}
\hline \multirow{2}{*}{$\begin{array}{l}\text { Crato } \\
\text { SV }\end{array}$} & \multirow{2}{*}{-DF } & \multicolumn{9}{|c|}{ Mean Square } \\
\hline & & $\mathrm{SDM}$ & $\mathrm{RDM}$ & NPP & $\mathrm{PL}$ & PW & NSP & WSP & $100 \mathrm{SW}$ & YIELD \\
\hline Block & 3 & 59.11 & 0.19 & 7.18 & 0.69 & 1.63 & 2.54 & 0.19 & 5.84 & 253.072 \\
\hline sources of $\mathrm{N}(\mathrm{SN})$ & 3 & $27.47 \mathrm{~ns}$ & $0.54 \mathrm{~ns}$ & $6.76 \mathrm{~ns}$ & $0.72 \mathrm{~ns}$ & $2.64 \mathrm{~ns}$ & $1.18 \mathrm{~ns}$ & $0.18 \mathrm{~ns}$ & $3.45 \mathrm{~ns}$ & $29.953 \mathrm{~ns}$ \\
\hline Cultivars (C) & 2 & $45.69 *$ & $0.53 \mathrm{~ns}$ & $57.90 * *$ & $33.60 * *$ & $0.60 \mathrm{~ns}$ & $13.39 *$ & $0.00 \mathrm{~ns}$ & $32.88 * *$ & $98.271 \mathrm{~ns}$ \\
\hline $\mathrm{SN} \times \mathrm{C}$ & 6 & $30.23 *$ & $0.30 \mathrm{~ns}$ & $4.70 \mathrm{~ns}$ & $0.48 \mathrm{~ns}$ & $1.15 \mathrm{~ns}$ & $0.92 \mathrm{~ns}$ & $0.10 \mathrm{~ns}$ & $2.89 \mathrm{~ns}$ & $18.828 \mathrm{~ns}$ \\
\hline CV $(\%)$ & & 16.04 & 14.13 & 24.00 & 4.85 & 51.51 & 11.93 & 14.08 & 7.77 & 32.43 \\
\hline Madalena & \multirow{2}{*}{$-\mathrm{DF}$} & \multicolumn{9}{|c|}{ Mean Square } \\
\hline $\mathrm{SV}$ & & SDM & RDM & NPP & PL & PW & NSP & WSP & P100SW & YIELD \\
\hline Block & 3 & 61.11 & 1.81 & 28.51 & 0.84 & 0.21 & 1.45 & 0.13 & 2.08 & 27726 \\
\hline sources of $\mathrm{N}(\mathrm{SN})$ & 3 & $9.03 \mathrm{~ns}$ & $0.21 \mathrm{~ns}$ & $8.82 \mathrm{~ns}$ & $0.10 \mathrm{~ns}$ & $0.04 \mathrm{~ns}$ & $0.57 \mathrm{~ns}$ & $0.08 \mathrm{~ns}$ & $4.63 \mathrm{~ns}$ & $1273 \mathrm{~ns}$ \\
\hline Cultivars (C) & 2 & $1.46 \mathrm{~ns}$ & $0.09 \mathrm{~ns}$ & $2.97 \mathrm{~ns}$ & $46.36 * *$ & $0.22 \mathrm{~ns}$ & $20.39 * *$ & $0.11 \mathrm{~ns}$ & $66.95 \mathrm{~ns}$ & $1224 \mathrm{~ns}$ \\
\hline $\mathrm{SN} \times \mathrm{C}$ & 6 & $12.15 \mathrm{~ns}$ & $0.24 \mathrm{~ns}$ & $20.91 \mathrm{~ns}$ & $0.21 \mathrm{~ns}$ & $0.05 \mathrm{~ns}$ & $0.33 \mathrm{~ns}$ & $0.06 \mathrm{~ns}$ & $2.95 \mathrm{~ns}$ & $21260 \mathrm{~ns}$ \\
\hline CV $(\%)$ & & 30.46 & 23.46 & 49.01 & 4.12 & 9.02 & 7.73 & 10.63 & 16.05 & 18.48 \\
\hline
\end{tabular}

Note. Source of Variation (SV), Degrees of Freedom (DF), Shoot Dry Matter (SDM), Root Dry Matter (RDM), Number of Pods per Plant (NPP), Pod Length (PL), Pod Weight (PW), Number of Seeds per Pod (NSP), Weight of Seeds per Pod (WSP), 100 Seed Weight (100SW) and Yield (YIELD), ** Significant at $1 \%$ by the F test, * Significant at $5 \%$ by the $\mathrm{F}$ test, not significant (ns).

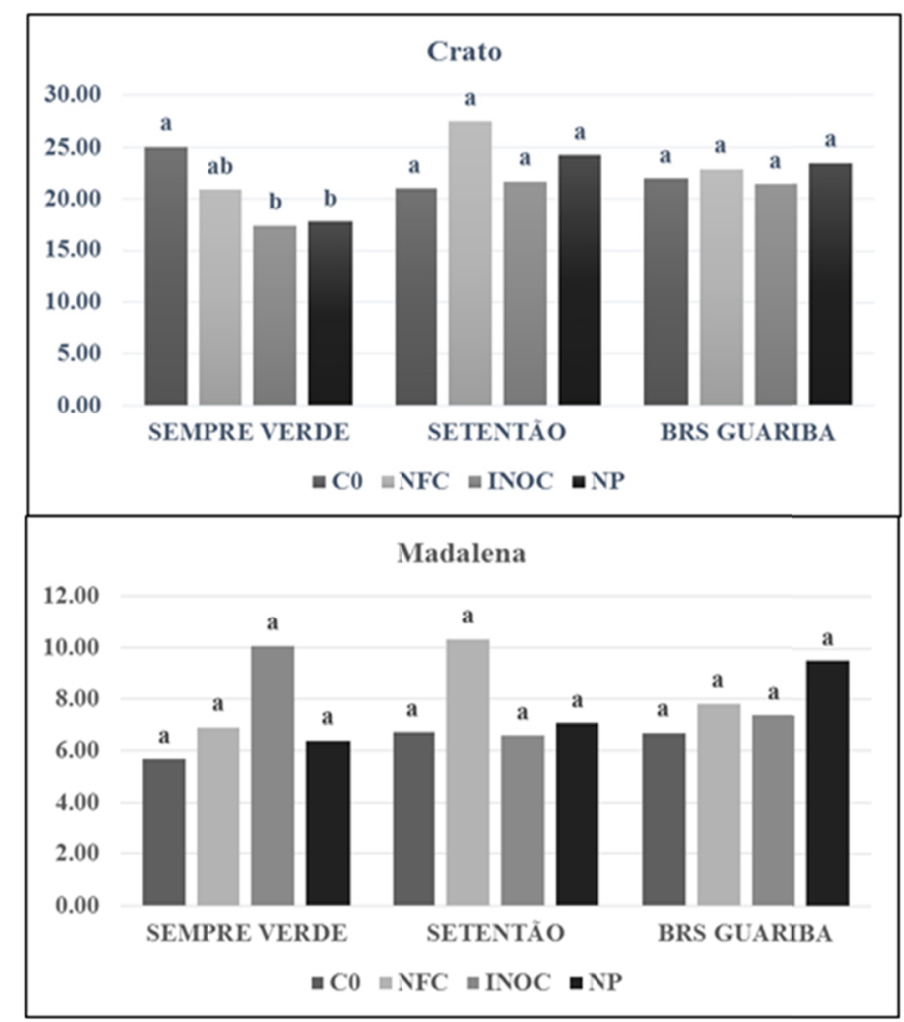

Figure 1. Shoot dry matter of cowpea plants $\left(\mathrm{g} \mathrm{pl}^{-1}\right)$ under different forms of nitrogen in Crato and Madalena, CE, Brazil.

Note. C0: absolute control without $\mathrm{N}$ and without inoculant; NFC: mineral nitrogen fertilization with $50 \mathrm{~kg} \mathrm{ha}^{-1}$ of N; INOC: commercial inoculant; NP: nodule preparation. Mean values followed by the same letter do not differ from each other by the Tukey test at the level of $5 \%$ probability. 
In the experiment conducted in Madalena, there were no differences among the cultivars or among the sources of $\mathrm{N}$ (Figure 1), although the commercial inoculant exhibited superiority to the other treatments when inoculated on the cultivar Sempre Verde. The same was observed for the cultivar Setentão, however, when the mineral nitrogen treatment was used. Furthermore, in the case of the cultivar BRS Guariba, there was an increase of $42 \%$ in the plot with application of the nodule preparation compared to $\mathrm{C} 0$, reaching a value of $9.53 \mathrm{~g} \mathrm{plant}^{-1}$. In this sense, the means for this variable within the Madalena environment were lower, indicating less plant growth, probably as a result of environmental responses. Mean rainfall for Crato was $440 \mathrm{~mm}$ throughout the period of the experiment, whereas in Madalena, mean rainfall values were lower, around $280 \mathrm{~mm}$ (FUNCEME, 2017).

The RDM in the experiment in Crato (Table 3), in the same way as the previous variable, showed little variation, with more notable differences within the cultivar Setentão, where the mineral nitrogen treatment was superior to that of the commercial inoculant, with mean values of 4.21 and $3.25 \mathrm{~g}$ of roots per plant, respectively. The nodule preparation treatment had an intermediate value ( $3.5 \mathrm{~g}$ of roots). Differences were observed among the cowpea cultivars within the mineral N treatment; the cultivar Setentão had a better result than the cultivars BRS Guariba and Sempre Verde. In relation to the Madalena experiment, there was significant variation only among the cultivars and considering only the nodule preparation treatment. The greatest RDM was observed with the cv. BRS Guariba (1.98 g of roots), significantly superior to that of the cultivar Sempre Verde, with $1.34 \mathrm{~g}$ of roots (Table 4).

Table 3. Mean of production variables evaluated for three cowpea cultivars under different sources of $\mathrm{N}$ in Crato, CE, Brazil

\begin{tabular}{|c|c|c|c|c|c|c|c|c|c|c|}
\hline \multirow{3}{*}{$\begin{array}{l}\text { Treat. } \\
\mathrm{C} 0\end{array}$} & \multicolumn{3}{|c|}{ RDM (g) } & \multirow{3}{*}{$\frac{\text { Trait }}{\mathrm{C} 0}$} & \multicolumn{6}{|c|}{ NSP (unit) } \\
\hline & S. Verde & Setentão & BRS Guariba & & \multicolumn{2}{|c|}{ S. Verde } & \multicolumn{2}{|c|}{ Setentão } & \multicolumn{2}{|c|}{ BRS Guariba } \\
\hline & $3.66 \mathrm{Aa}$ & $3.32 \mathrm{Aab}$ & $3.61 \mathrm{Aa}$ & & 13.10 & $\mathrm{Aa}$ & 12.75 & $\mathrm{Aa}$ & 13.95 & $\mathrm{Aa}$ \\
\hline NFC & $3.27 \mathrm{Ba}$ & $4.21 \mathrm{Aa}$ & $3.79 \mathrm{ABa}$ & $\mathrm{NFC}$ & 12.75 & $\mathrm{Aa}$ & 12.90 & $\mathrm{Aa}$ & 15.40 & $\mathrm{Aa}$ \\
\hline INOC & $3.00 \mathrm{Aa}$ & $3.25 \mathrm{Ab}$ & $3.51 \mathrm{Aa}$ & INOC & 12.90 & $\mathrm{Aa}$ & 12.80 & $\mathrm{Aa}$ & 14.75 & $\mathrm{Aa}$ \\
\hline \multirow[t]{2}{*}{ NP } & $3.18 \mathrm{Aa}$ & $3.50 \mathrm{Aab}$ & $3.54 \mathrm{Aa}$ & NP & 12.75 & $\mathrm{Aa}$ & 12.60 & $\mathrm{Aa}$ & 13.50 & $\mathrm{Aa}$ \\
\hline & \multicolumn{3}{|c|}{ NPP (unit) } & & \multicolumn{6}{|c|}{ WSP (g) } \\
\hline $\mathrm{C} 0$ & $11.75 \mathrm{Aa}$ & $10.50 \mathrm{Aa}$ & $9.38 \mathrm{Aa}$ & $\overline{\mathrm{C} 0}$ & 2.70 & $\mathrm{Aa}$ & 2.51 & $\mathrm{Aa}$ & 2.59 & $\mathrm{Aa}$ \\
\hline NFC & $11.63 \mathrm{Aa}$ & $14.25 \mathrm{Aa}$ & $10.38 \mathrm{Aa}$ & NFC & 2.58 & $\mathrm{Aa}$ & 2.84 & $\mathrm{Aa}$ & 2.97 & $\mathrm{Aa}$ \\
\hline INOC & $11.63 \mathrm{Aa}$ & $12.38 \mathrm{Aa}$ & $7.75 \mathrm{Aa}$ & INOC & 2.79 & $\mathrm{Aa}$ & 2.67 & $\mathrm{Aa}$ & 2.66 & $\mathrm{Aa}$ \\
\hline \multirow[t]{2}{*}{ NP } & $11.50 \mathrm{Aba}$ & $12.63 \mathrm{Aa}$ & $7.75 \mathrm{Ba}$ & $\mathrm{NP}$ & 2.60 & $\mathrm{Aa}$ & 2.58 & $\mathrm{Aa}$ & 2.36 & $\mathrm{Aa}$ \\
\hline & \multicolumn{3}{|c|}{ PL (cm) } & & \multicolumn{6}{|c|}{ 100SW (g) } \\
\hline $\mathrm{CO}$ & $20.23 \mathrm{Aa}$ & $17.50 \mathrm{Ba}$ & $17.60 \mathrm{Ba}$ & $\overline{\mathrm{C} 0}$ & 20.62 & $\mathrm{Aa}$ & 19.55 & $\mathrm{Aa}$ & 18.58 & $\mathrm{Aa}$ \\
\hline NFC & $20.10 \mathrm{Aa}$ & $17.33 \mathrm{Ba}$ & $18.88 \mathrm{ABa}$ & NFC & 20.27 & $\mathrm{ABa}$ & 22.12 & $\mathrm{Aa}$ & 19.29 & $\mathrm{Ba}$ \\
\hline INOC & $20.25 \mathrm{Aa}$ & $17.38 \mathrm{Ba}$ & $18.00 \mathrm{Ba}$ & INOC & 21.60 & $\mathrm{Aa}$ & 20.78 & $\mathrm{Aa}$ & 18.05 & $\mathrm{Ba}$ \\
\hline \multirow[t]{2}{*}{ NP } & $19.80 \mathrm{Aa}$ & $16.95 \mathrm{Ba}$ & $17.78 \mathrm{Ba}$ & NP & 20.38 & $\mathrm{Aa}$ & 20.64 & $\mathrm{Aa}$ & 17.13 & $\mathrm{Ba}$ \\
\hline & \multicolumn{3}{|c|}{ PW (g) } & & \multicolumn{6}{|c|}{ YIELD $\left(\mathrm{kg} \mathrm{ha}^{-1}\right)$} \\
\hline $\mathrm{C} 0$ & $3.33 \mathrm{Aa}$ & $3.61 \mathrm{Aa}$ & $3.29 \mathrm{Aa}$ & $\overline{\mathrm{C} 0}$ & 476.25 & $\mathrm{Aa}$ & 597.79 & $\mathrm{Aa}$ & 551.21 & $\mathrm{Aa}$ \\
\hline NFC & $5.26 \mathrm{Aa}$ & $3.83 \mathrm{Aa}$ & $3.89 \mathrm{Aa}$ & NFC & 573.26 & $\mathrm{Aa}$ & 614.19 & $\mathrm{Aa}$ & 657.54 & $\mathrm{Aa}$ \\
\hline INOC & $3.54 \mathrm{Aa}$ & $3.67 \mathrm{Aa}$ & $3.44 \mathrm{Aa}$ & INOC & 481.10 & $\mathrm{Aa}$ & 585.41 & $\mathrm{Aa}$ & 526.20 & $\mathrm{Aa}$ \\
\hline NP & $3.22 \mathrm{Aa}$ & $3.44 \mathrm{Aa}$ & $3.19 \mathrm{Aa}$ & NP & 438.68 & $\mathrm{Ba}$ & 781.24 & $\mathrm{Aa}$ & 666.83 & $\mathrm{ABa}$ \\
\hline
\end{tabular}

Note. Mean values followed by the same uppercase letter in the line and by the same lowercase letter in the column do not differ from each other by the Tukey test at $5 \%$ probability. Legend: $\mathrm{C} 0$-absolute control without $\mathrm{N}$ and without inoculant, NFC-Nitrogen Fertilized Control with $50 \mathrm{~kg} \mathrm{ha}^{-1}$ of N, INOC-Commercial Inoculant, NP-Nodule Preparation, Root Dry Matter (RDM), Number of Seeds per Pod (NSP), Number of Pods per Plant (NPP), Weight of Seeds per Pod (WSP), Pod Length (PL), 100 Seed Weight (100SW), Pod Weight (PW), and Yield (YIELD).

In relation to the NPP for the experiment in Crato, significant differences were only found among the cultivars that received the nodule preparation. The cv. Setentão exhibited a mean of 12.63 units, a mean superior to BRS Guariba; nevertheless, the highest value observed for this variable was 14.25 in reference to the cultivar Setentão fertilized with urea (Table 3). Statistical differences were not observed, however. The results from Madalena show an absence of significant differences; the means were in the interval from 7.88 (cv. Setentão and nodule preparation) to 13.25 (nitrogen fertilization and the cultivar Sempre Verde) (Table 4). Such values are near those 
observed by Matos Filho et al. (2009), who obtained values from 8.43 to $12.13 \mathrm{~cm}$ in reference to diverse cowpea progenies and lines.

The PL variable was quite affected by the choice of cultivar, and Sempre Verde was superior to the others in both locations, showing that this response is associated with the cultivar. The mean size of the pods for the cv. Sempre Verde was approximately $20 \mathrm{~cm}$, which is within the commercial standard (Silva \& Neves, 2011).

Although the cv. Sempre Verde exhibited longer pods, this did not lead to greater NSP, showing a mean value lower than 13 seeds. However, the cv. BRS Guariba had higher values for this variable in both locations, ranging from 13.5 to 15.4 seeds in Crato (Table 3) and from 13.9 to 15.1 seeds in Madalena (Table 4). Such values agree with Silva et al. (2016), who obtained values in the range of 13.13 to 15.83 seeds in evaluating 20 genotypes in Roraima. This difference, especially between Sempre Verde and BRS Guariba, can be found when we observe $100 \mathrm{SW}$, in which the cv. BRS Guariba had inferior mean values compared to the other cultivars, in both locations of evaluation.

Table 4. Mean of production variables evaluated for three cowpea cultivars under different sources of $\mathrm{N}$ in Madalena, CE, Brazil

\begin{tabular}{|c|c|c|c|c|c|c|c|c|c|}
\hline \multirow{3}{*}{$\begin{array}{l}\text { Treat. } \\
\mathrm{C} 0\end{array}$} & \multicolumn{3}{|c|}{ RDM (g) } & \multirow{3}{*}{$\begin{array}{l}\text { Trait } \\
\mathrm{C} 0\end{array}$} & \multicolumn{5}{|c|}{ NSP (unit) } \\
\hline & S. Verde & Setentão & BRS Guariba & & \multicolumn{2}{|c|}{ S. Verde } & Setentão & \multicolumn{2}{|c|}{ BRS Guariba } \\
\hline & $1.19 \mathrm{Aa}$ & $1.28 \mathrm{Aa}$ & $1.45 \mathrm{Aa}$ & & 12.45 & $\mathrm{Ba}$ & $13.30 \mathrm{Aba}$ & 14.80 & $\mathrm{Aa}$ \\
\hline NFC & $1.49 \mathrm{Aa}$ & $1.82 \mathrm{Aa}$ & $1.40 \mathrm{Aa}$ & NFC & 12.45 & $\mathrm{Ba}$ & $12.85 \mathrm{Ba}$ & 14.70 & $\mathrm{Aa}$ \\
\hline INOC & $1.65 \mathrm{Aa}$ & $1.33 \mathrm{Aa}$ & $1.45 \mathrm{Aa}$ & INOC & 12.45 & $\mathrm{Aa}$ & $12.85 \mathrm{Aa}$ & 13.90 & $\mathrm{Aa}$ \\
\hline \multirow[t]{2}{*}{ NP } & $1.34 \mathrm{Ba}$ & $1.51 \mathrm{Aba}$ & $1.98 \mathrm{Aa}$ & NP & 12.45 & $\mathrm{Ba}$ & $13.05 \mathrm{Ba}$ & 15.10 & $\mathrm{Aa}$ \\
\hline & \multicolumn{3}{|c|}{ NPP (unit) } & & \multicolumn{5}{|c|}{ WSP (g) } \\
\hline $\mathrm{CO}$ & $9.38 \mathrm{Aa}$ & $11.88 \mathrm{Aa}$ & $9.50 \mathrm{Aa}$ & $\mathrm{CO}$ & 2.68 & $\mathrm{Aa}$ & $2.99 \mathrm{Aa}$ & 2.57 & $\mathrm{Aa}$ \\
\hline NFC & $13.25 \mathrm{Aa}$ & $12.63 \mathrm{Aa}$ & $10.88 \mathrm{Aa}$ & NFC & 2.69 & $\mathrm{Aa}$ & 2.64 & 2.72 & $\mathrm{Aa}$ \\
\hline INOC & $12.25 \mathrm{Aa}$ & $11.75 \mathrm{Aa}$ & $10.38 \mathrm{Aa}$ & INOC & 2.67 & $\mathrm{Aa}$ & $2.68 \mathrm{Aa}$ & 2.44 & $\mathrm{Aa}$ \\
\hline \multirow[t]{2}{*}{ NP } & $11.88 \mathrm{Aa}$ & $7.88 \mathrm{Aa}$ & $12.75 \mathrm{Aa}$ & NP & 2.54 & $\mathrm{Aa}$ & $2.63 \mathrm{Aa}$ & 2.56 & $\mathrm{Aa}$ \\
\hline & \multicolumn{3}{|c|}{ PL (cm) } & & \multicolumn{5}{|c|}{ 100SW (g) } \\
\hline $\mathrm{CO}$ & $20.40 \mathrm{Aa}$ & $16.98 \mathrm{Ba}$ & $17.88 \mathrm{Ba}$ & T0 & 21.56 & $\mathrm{Aa}$ & $22.71 \mathrm{Aa}$ & 17.39 & $\mathrm{Ba}$ \\
\hline NFC & $20.63 \mathrm{Aa}$ & $16.88 \mathrm{Ba}$ & $18.05 \mathrm{Ba}$ & NFC & 21.58 & $\mathrm{Aa}$ & $20.60 \mathrm{Aa}$ & 18.53 & $\mathrm{Aa}$ \\
\hline INOC & $19.85 \mathrm{Aa}$ & $17.05 \mathrm{Ba}$ & $18.03 \mathrm{Ba}$ & INOC & 21.41 & $\mathrm{Aa}$ & $20.89 \mathrm{ABa}$ & 17.55 & $\mathrm{Ba}$ \\
\hline \multirow[t]{2}{*}{ NP } & $20.18 \mathrm{Aa}$ & $16.80 \mathrm{Ba}$ & $18.10 \mathrm{Ba}$ & NP & 20.37 & $\mathrm{Aa}$ & $20.01 \mathrm{ABa}$ & 16.94 & $\mathrm{Ba}$ \\
\hline & \multicolumn{3}{|c|}{ PW (g) } & & \multicolumn{5}{|c|}{ YIELD $\left(\mathrm{kg} \mathrm{ha}^{-1}\right)$} \\
\hline $\mathrm{C} 0$ & $3.37 \mathrm{Aa}$ & $3.53 \mathrm{Aa}$ & $3.26 \mathrm{Aa}$ & $\mathrm{C} 0$ & 507.43 & $\mathrm{Aa}$ & 577.15 Aab & 494.09 & $\mathrm{Aa}$ \\
\hline NFC & $3.34 \mathrm{Aa}$ & $3.45 \mathrm{Aa}$ & $3.49 \mathrm{Aa}$ & NFC & 490.21 & $\mathrm{Aa}$ & $596.02 \mathrm{Aa}$ & 530.22 & $\mathrm{Aa}$ \\
\hline INOC & $3.33 \mathrm{Aa}$ & $3.59 \mathrm{Aa}$ & $3.14 \mathrm{Aa}$ & INOC & 503.66 & $\mathrm{Aa}$ & $572.35 \mathrm{Aab}$ & 506.65 & $\mathrm{Aa}$ \\
\hline NP & $3.20 \mathrm{Aa}$ & $3.43 \mathrm{Aa}$ & $3.23 \mathrm{Aa}$ & NP & 574.18 & $\mathrm{Aa}$ & $398.79 \mathrm{Bb}$ & 567.92 & $\mathrm{Aa}$ \\
\hline
\end{tabular}

Note. Mean values followed by the same uppercase letter in the line and by the same lowercase letter in the column do not differ from each other by the Tukey test at 5\% probability. Legend: NFC-Nitrogen Fertilized Control with $50 \mathrm{~kg} \mathrm{ha}^{-1}$ of N, INOC-Commercial Inoculant, NP-Nodule Preparation, Root Dry Matter (RDM), Number of Seeds per Pod (NSP), Number of Pods per Plant (NPP), Weight of Seeds per Pod (WSP), Pod Length (PL), 100 Seed Weight (100SW), Pod Weight (PW), and Yield (YIELD).

In relation to seed production, the mean yield was $579 \mathrm{~kg} \mathrm{ha}^{-1}$ in Crato and $526 \mathrm{~kg} \mathrm{ha}^{-1}$ in Madalena, exceeding the Brazilian average of $506 \mathrm{~kg} \mathrm{ha}^{-1}$ in the 2016/2017 crop season (CONAB, 2018). In addition, the two highest values obtained for the experiment in Crato were $781 \mathrm{~kg} \mathrm{ha}^{-1}$ for the cv. Setentão plus the nodule preparation and $667 \mathrm{~kg} \mathrm{ha}^{-1}$ for the $\mathrm{cv}$. BRS Guariba plus the nodule preparation (Table 3). The mean yields were at levels lower than the values generally obtained under experimental conditions because the population adopted was approximately 41,600 plants, similar to that adopted by small farmers. In contrast, some studies, such as Silva et al. (2016) and Souza et al. (2017), adopt more than 100,000 plants ha ${ }^{-1}$, achieving yields of 1,200 and 1,400 kg $\mathrm{ha}^{-1}$, respectively. In addition, the two experiments were set up on dryland that, together with low rainfall indices, compromise production.

The nodule preparation proved to have little effect under the conditions presented, both in relation to the treatment with commercial inoculant and in relation to the absolute control, in both locations. The commercial 
inoculant maintained a mean very near that of the nodule preparation and that of the nitrogen treatment, but without statistical differences from the absolute control. The yield generated by the NP in Crato was $628 \mathrm{~kg} \mathrm{ha}^{-1}$, whereas in the NFC, it was $614 \mathrm{~kg} \mathrm{ha}^{-1}$, a difference of $2.3 \%$. In Madalena, for its part, the NP produced only $513 \mathrm{~kg} \mathrm{ha}^{-1}$ and the NFC obtained $539 \mathrm{~kg} \mathrm{ha}^{-1}$, which represents a reduction of $4.6 \%$ for the NP. Rocha (2013) observed gains of $32 \%$ with the nodule preparation over the absolute control in evaluation of cowpea plants at 28 days in a greenhouse. However, at 35 days, the gains were only $15 \%$. This shows how responses can change according to conditions such as plant age and, especially, when the treatments and cultivars are evaluated under field crop conditions. There is the action of the community of soil microorganisms that interact among themselves, promoting plant growth and increasing soil fertility through phosphate solubilization and also biological nitrogen fixation (Costa \& Melo, 2012; Ryan et al., 2008). In addition, in both locations, there was a history of cowpea cultivation, reinforcing the idea of a well-established, $\mathrm{N}$-fixing microbial community.

In addition, the increases in concentration of bacterial cells on the seed surface increase the rhizobia population that occupies the nodulation sites at the plant root, while the low density of rhizobia cells, together with the low specificity of cowpea in relation to the microsymbiont, may be one of the explanations for the low response of the plant to inoculation (Silva Júnior et al., 2014). Moreover, in relation to the nodule preparation, the number of cells that are applied on the seed surface may still be low, and additional and more detailed tests are necessary with different concentrations of nodules at different locations to show which situation is more advantageous.

\section{Conclusion}

The use of the nodule preparation led to yield identical to that from the commercial inoculant and from $\mathrm{N}$ fertilization in both locations evaluated.

The response from the nodule preparation can change according to the crop region in response to the existing microbial community.

\section{References}

Alcântara, R. M. C. M., Xavier, G. R., Rumjanek, N. G., Rocha, M. M., \& Carvalho, J. S. (2014). Eficiência simbiótica de progenitores de cultivares brasileiras de feijão-caupi. Revista Ciencia Agronomica, 45, 1-9. https://doi.org/10.1590/S1806-66902014000100001

CONAB (Companhia Nacional de Abastecimento). (2018). Acompanhamento da safra brasileira de grãos-Safra 2017/18. Retrieved from https://www.conab.gov.br/index.php/info-agro/safras

Costa, F. E. D. C., \& Melo, I. S. (2012). Endophytic and rhizospheric bacteria from Opuntia ficus-indica mill and their ability to promote plant growth in cowpea, Vigna unguiculata (L.) Walp. African Journal of Microbiology Research, 6, 1345-1353. https://doi.org/10.5897/AJMR11.1503

Cruz, C. D. (2013). GENES - Software para análise de dados em estatística experimental e em genética quantitativa. Acta Scientiarum Agronomy, 35, 271-276.

FUNCEME (Fundação Cearense de Meteorologia). (2017). Chuva mensal. Retrieved from http://funceme.br/ app/calendario/produto/bacias/media/mensal?data $=2017-2-1$

Guimarães, A. A., Jaramillo, P. M. D., Nóbrega, R. S. A., Florentino, L. A., Silva, K. B., \& Moreira, F. M. S. (2012). Genetic and symbiotic diversity of nitrogen-fixing bacteria isolated from agricultural soils in the western amazon by using cowpea as the trap plant. Applied Environmental Microbiology, 78, 6726-6733. https://doi.org/10.1128/AEM.01303-12

Kambashi, B., Boudry, C., Picron, P., \& Bindelle, J. (2014). Forage plants as an alternative feed resource for sustainable pig production in the tropics: A review. Animal, 8, 1298-1311. https://doi.org/10.1017/ S1751731114000561

Matos Filho, C. H. A., Gomes, R. L. F., Rocha, M. M., Freire Filho, F. R., \& Lopes, A. C. A. (2009). Potencial produtivo de progênies de feijão-caupi com arquitetura ereta de planta. Ciência Rural, 39, 348-354. https://doi.org/10.1590/S0103-84782009000200006

Moreira, F. M. S. (2006). Nitrogen-fixing Leguminosae-nodulating bacteria. In F. M. S. Moreira, J. O. Siqueira, \& L. Brussaard (Eds.), Soil biodiversity in Amazonian and other Brazilian ecosystems (pp. 237-270). Wallingford: CAB International. https://doi.org/10.1079/9781845930325.0237

Moreira, F. M. S., \& Siqueira, J. O. (2006). Microbiologia e biotecnologia do solo (2nd ed.). Lavras: Editora UFLA. 
Oldroyd, G. E. D. (2013). Speak friend, and enter: Signalling systems that promote beneficial symbiotic associations in plants. Nature Publishing Group, 11, 252-263. https://doi.org/10.1038/nrmicro2990

Pimentel-Gomes, F., \& Garcia, C. H. (2002). Estatística aplicada a experimentos agronômicos e florestais: Exposição com exemplos e orientações para uso de aplicativos. Piracicaba: FEALQ.

Phillips, R. D., McWatters, K. H., Chinnan, M. S., Hung, Y.-C., Beuchat, L. R., Sefa-Dedeh, S., ... Saalia, F. K. (2003). Utilization of cowpeas for human food. Field Crops Research, 82, 193-213. https://doi.org/10.1016/ S0378-4290(03)00038-8

Reis Júnior, F. B., Mendes, I. C., Reis, V. M., \& Hungria, M. (2011). Fixação biológica de nitrogênio: uma revolução na agricultura. In F. G. Faleiro, S. R. M. Andrade, \& F. B. Reis Júnior (Eds.), Biotecnologia: Estado da arte e aplicações na agropecuária (pp. 247-319). Planaltina: Embrapa Cerrados.

Rocha, B. M. (2013). Prática alternativa de inoculação de sementes de feijoeiro (Phaseolus vulgaris, cv. Ouro Vermelho) com estirpes rizobianas localmente adaptadas (Unpublished master's thesis, Federal University of Ceara, Fortaleza, Brazil).

Rufini, M., Silva, M. A. P., Ferreira, P. A. A., Cassetari, A. S., Soares, B. L., Andrade, M. J. B., \& Moreira, F. M. S. (2014). Symbiotic efficiency and identification of rhizobia that nodulate cowpea in a Rhodic Eutrudox. Biology and Fertility of Soils, 50, 115-122. https://doi.org/10.1007/s00374-013-0832-4

Ryan, R. P., Germaine, K., Franks, A., Ryan, D. J., \& Dowling, D. N. (2008). Bacterial endophytes: Recent developments and applications. FEMS Microbiology Letters, 278, 1-9. https://doi.org/10.1111/j.1574-6968. 2007.00918.x

Sanginga, N., Abaidoo, R., Dashiell, K., Carsky, R. J., \& Okogun, K. (1996). Persistence and effectiveness of rhizobia nodulating promiscuous soybeans in moist savanna zones of Nigeria. Applied Soil Ecology, 3, 215-224. https://doi.org/10.1016/0929-1393(95)00089-5

Silva, G. C., Magalhães, R. C., Sobreira, A. C., Schmitz, R., \& Silva, L. C. (2016). Rendimento de grãos secos e componentes de produção de genótipos de feijão-caupi em cultivo irrigado e de sequeiro. Revista Agro@mbiente on-Line, 10,342-350. https://doi.org/10.18227/1982-8470ragro.v10i4.3385

Silva, J. A. L., \& Neves, J. (2011). Componentes de produção e suas correlações em genótipos de feijão-caupi em cultivo de sequeiro e irrigado. Revista Ciencia Agronomica, 42, 702-713. https://doi.org/10.1590/ S1806-66902011000300017

Silva Júnior, E. B., Silva, K., Oliveira, S. S., Oliveira, P. J., Boddey, R. M., Zilli, J. E., \& Xavier, G. R. (2014). Nodulação e produção de feijão-caupi em resposta à inoculação com diferentes densidades rizobianas. Pesquisa Agropecuaria Brasileira, 49, 804-812. https://doi.org/10.1590/S0100-204X2014001000007

Sinnsiri, W., \& Homchan, J. (2002). Effect of rhizobial management upon rhizobial population, nodulation and growth of yard long beans (Vigna sesquipedalis L.): A New approach to maximize benefits from rhizobium. Pakistan Journal of Biological Sciences, 5, 25-28. https://doi.org/10.3923/pjbs.2002.25.28

Soares, C. S. (2007). Eficiência de estirpes de rizóbios no rendimento e qualidade fisiológica de sementes de Feijão-acupi (Unpublished doctoral dissertation, Federal University of Paraíba, Fortaleza, Brazil).

Souza, P. J. O. P., Farias, V. D. S., Lima, M. J. A., Ramos, T. F., \& Sousa, A. M. L. (2017). Cowpea leaf area, biomass production and productivity under different water regimes in Castanhal, Pará, Brazil. Revista Caatinga, 30, 748-759. https://doi.org/10.1590/1983-21252017v30n323rc

Timko, M. P., Ehlers, J. D., \& Roberts, P. A. (2007). Cowpea. In C. Kole (Ed.), Genome Mapping and Molecular Breeding in Plants (pp. 49-67). Springer Verlag, Berlin. Heidelberg. https://doi.org/10.1007/ 978-3-540-34516-9_3

\section{Copyrights}

Copyright for this article is retained by the author(s), with first publication rights granted to the journal.

This is an open-access article distributed under the terms and conditions of the Creative Commons Attribution license (http://creativecommons.org/licenses/by/4.0/). 